\title{
The Civic Informatics of FracTracker Alliance: Working with Communities to Understand the Unconventional Oil and Gas Industry
}

\author{
KIRK JALBERT ${ }^{1}$ \\ FRACTRACKER ALLIANCE AND DREXEL UNIVERSITY \\ SAMANTHA Malone Rubright \\ FRACTRACKER ALLIANCE \\ KAREN EDELSTEIN \\ FRACTRACKER AlLIANCE
}

\begin{abstract}
Unconventional oil and gas extraction is fueling a wave of resource development often touted as a new era in US energy independence. However, assessing the true costs of extraction is made difficult by the vastness of the industry and lack of regulatory transparency. This paper addresses efforts to fill knowledge gaps taken up by civil society groups, where the resources produced in these efforts are used to make informed critiques of extraction processes and governance. We focus on one civil society organization, called FracTracker Alliance, which works to enhance public understanding by collecting, interpreting, and visualizing oil and gas data in broad partnerships. Drawing on the concepts of civic science, we suggest that the informational practices of civil society research organizations facilitate critical knowledge flows that we term "civic informatics." We offer three case studies illustrating how different characteristics of civic informatics enable public-minded research as well as build capacity for political mobilizations. Finally, we suggest that empirical studies of civic informatics and its facilitators offer insights for the study of "engaged" Science and Technologies Studies (STS) that seek to generate new models of science at the intersection of praxis and theory.
\end{abstract}

\footnotetext{
${ }^{1}$ Kirk Jalbert, Email: jalbert@fractracker.org

Copyright (c) 2017 (Kirk Jalbert, Samantha Malone, and Karen Edelstein). Licensed under the Creative Commons Attribution Non-commercial No Derivatives (by-nc-nd). Available at estsjournal.org.
} 


\section{Keywords}

civic informatics; civic science; oil and gas extraction; government transparency; engaged STS

\section{Introduction}

Geologists have known for decades that shale rock formations in the US contained extensive fossil fuel deposits, but the technologies needed to retrieve trapped oil and gas at depths of up to 10,000 feet below the surface, namely horizontal drilling and high-volume hydraulic fracturing, only became viable in the past few decades (Soeder and Kappel 2009; United States Energy Information Agency 1993). Communities assessing the potential risks of this new form of "unconventional" oil and gas development (UOGD) faced numerous challenges. ${ }^{2}$ Many states lacked procedures that required energy companies to disclose the locations of proposed wells, the chemical makeup of their drilling fluids, or to directly notify the public of regulatory violations (Maule et al. 2013). Meanwhile, proponents of UOGD promised jobs, tax revenue, and lucrative land deals for regions seeking economic revitalization. These narratives were largely propagated by public relations campaigns and industry-backed media outlets that sought to delegitimize precautionary approaches as alarmist (Matz and Renfrew 2015; Cooley and Casagrande 2017). Significant knowledge gaps were at the heart of debates about the safety and feasibility of UOGD from its infancy.

In the absence of adequate public understanding of the industry-as well as a slow-toarrive academic research community (Hays and Shonkoff 2016)—early investigations were largely taken up by a network of concerned citizen groups, advocacy organizations, and nonprofit technical service providers. Citizen science air and water monitoring programs sought to collect data in threatened communities (Khan 2016; Jalbert, Kinchy, and Perry 2014; Wylie and Dosemagen 2011). Other initiatives brought public health resources to assist affected residents and collected data on their symptoms, such as the Southwest Pennsylvania Environmental Health Project featured in this thematic collection (Rabinowitz et al. 2015; D. Brown et al. 2014). Others, still, took on an investigative reporting role to unearth regulatory discrepancies (Troutman, Shamer, and Pribanic 2017). We frame these collective engagements as an emergent

\footnotetext{
2 We prefer to use "unconventional oil and gas development" instead of other designations such as highvolume hydraulic fracturing or "fracking" in order to recognize that the impacts of the industry are not contained to the sites of extraction. One must also take into consideration the breadth of an infrastructure consisting of thousands of well pads, pipelines, waste processing plants, refineries, and other facilities that make energy extraction and distribution possible.
} 
civic science movement, what Fortun and Fortun $(2005,50)$ characterize as "a science that questions the state of things, rather than a science that simply serves the state."

In this paper, we evaluate another kind of actor within this movement that came together to assemble, analyze, and distribute UOGD related data. Yu and Robinson (2012) astutely note that government can call itself "open" if it builds a transparent-looking website, even if it does not afford new accountabilities. Such is the case with how most agencies have responded to requests for greater UOGD transparency. State and federal websites may host oil and gas related data but have done less to ensure their accuracy, completeness, or digestibility. These quasitransparencies, what Murphy (Murphy 2004) calls "regimes of imperceptibility," prevent concerned citizen groups from translating data into meaningful knowledge and ultimately enable the industry to claim compliance with requests for openness. One organization that emerged to contend with these opacities is FracTracker Alliance. FracTracker began as a public service project at the University of Pittsburgh's Graduate School of Public Health in 2010. Its initial objective was to obtain and map the location of UOGD wells and crowdsource regulatory violations in Pennsylvania's Marcellus Shale formation. In 2012, FracTracker reorganized as an independent non-profit, expanding its scope topically and geographically to address a wider range of issues related to the oil and gas industry.

FracTracker Alliance's contributions to UOGD debates are analyzed in three case studies. The first tells the story of how, in 2011, staff began mapping municipalities in New York State that had passed UOGD prohibitions by invoking "home rule" property governance laws. This mapping evolved into a participatory project with recursive impact; it informed the public on the extent of bans and moratoria, created an outlet for citizen groups to report on new proposals, and became a resource for archiving successful legislation. The second case study details FracTracker Alliance's mapping of crude oil trains traveling the nation's railways from North Dakota's Bakken Shale to East Coast refineries. Staff worked with partners to obtain rail carrier routes, identify high-risk communities, develop citizen science tools, and convene an educational summit. The final case study explores Knowing Our Waters, a FracTracker Alliance digital storytelling project produced in conjunction with citizen science water monitoring groups. Knowing Our Waters brought attention to how citizen scientists fill gaps in regulatory monitoring by creating a platform for participants to communicate their own narratives.

Using these examples, we observe how civic science reveals unique dimensions of informational praxis that we refer to as "civic informatics." Building on recent research exploring civic technoscience (Wylie et al. 2014), we argue that civic informatics pushes back against regimes of imperceptibility through very practical and highly collaborative data-driven research 
projects. Finally, we reflect on this thematic collections's discussions of "making and doing" science and technology studies (STS), suggesting that empirical studies of civic informatics provide insight for enhancing scholarly commitments to aiding and participating in publicminded science.

\section{Assessing the Risks of Unconventional Oil and Gas Extraction}

Public understanding of UOGD is made complex for many reasons. First, communities often struggle to fully grasp the footprint and political reach of the oil and gas industry. Its diffuse and ubiquitous infrastructure evades cumulative impact assessments and hinders efforts to mobilize citizens who might otherwise rise up against more centralized polluting facilities such as coal mines and megalandfills. Second, laws that govern UOGD do little to alleviate these "spatial knowledge gaps" (Roberts and Langston 2008). In many states, such as Pennsylvania, companies are only required to notify immediately-adjacent property owners of proposed oil and gas wells (Pennsylvania Department of Environmental Protection 2016). Others in the community typically learn of development plans after regulatory permits have been issued. Third, the industry has fought hard to remain opaque about its practices. In 2005, hydraulic fracturing was made exempt from the US Safe Drinking Water Act and the Clean Water Act (Warner and Shapiro 2013). Similarly, reporting requirements for hydrogen sulfide emissions that can result from drilling were lobbied out of the US Emergency Planning and Community Right-to-Know Act in 1994, later to be reinstated in 2012 (United States Environmental Protection Agency 2011).

These knowledge gaps create a number of challenges for a growing public concerned about UOGD. How do communities demarcate many sites of potential risk? How can they draw upon local knowledge and the resources of consultants to strategically reveal risk towards positive environmental and public health outcomes? How can they find shared identity in this work to build a movement across large geographies? Having access to timely and accurate UOGD related data was crucial to each of these objectives.

Data accessibility suffers from the sheer number of federal, state, and local government agencies responsible for managing the industry, each with their own standards of enforcement. For example, beginning in 2010, some states, facing public pressure to identify chemicals used in UOGD, began asking companies to disclose the contents of hydraulic fracturing fluids. In 2011, the Interstate Oil and Gas Compact Commission created FracFocus.org with support from industry groups to comply with this request. The volume of data on FracFocus.org quickly grew and, in 2014, the Department of Energy vouched for its efficacy (Dundon, Abkowitz, and Camp 
2015). FracFocus.org has since become the system of choice for companies when responding to state-level chemical disclosure requests, despite significant critiques from within the research community concerning critical design flaws and the veils of voluntary reporting (Konschnik, Holden, and Shasteen 2013).

Some data remain obscure due to issues of resource scarcity, technology inadequacies, and lack of enforcement in regulatory agencies. In our prior study of UOGD drilling data across ten states (Malone et al. 2015) we found that only six provided data on oil and gas waste management, and only four made violation reports public. Many datasets were made available as scanned images, which are the result of companies submitting required information on paper rather than in workable spreadsheets-a practice some have suggested intentionally burdens agencies and the public from processing their contents (Phillips 2016).

In other cases, we found states charged significant sums to access data. In Texas, for instance, one can view information pertaining to oil and gas wells for free, but obtaining the geospatial locations of wells can cost thousands of dollars. These revenue-generating models amount to asking citizens to pay twice for services they should rightly expect from public institutions. However, in speaking with agency representatives over time, we've also learned that their ability to respond to data requests are, more often than not, limited by understaffed offices and shrinking budgets.

\section{Filling Data Gaps: FracTracker Alliance}

It was in this moment of extreme informational need and opacity that FracTracker emerged. In 2010, Data.FracTracker.org (a public GIS portal also known as the "DataTool") and FracTracker.org (an accompanying blog) were launched by the University of Pittsburgh Graduate School of Public Health's Center for Healthy Environments and Communities (CHEC) with funding from two private foundations. Faculty at CHEC enlisted a small group of graduate students eager to engage with health issues related to drilling in the Marcellus Shale region of Pennsylvania. Their projects covered various aspects of the industry, including visually documenting impacts, air and water quality monitoring, and public health surveys (Ferrar, Kriesky, et al. 2013; Ferrar, Michanowicz, et al. 2013). The FracTracker.org blog was used to contextualize CHEC research with drilling maps and data analysis. At the same time, the DataTool provided an outlet to view and play with obtained data, where users could upload, download, comment on datasets, and generate their own maps. Approximately 1,300 users registered with the DataTool in its first five months, ranging from watershed organizations, to 
advocacy groups, to individual citizens living in extraction communities (Michanowicz et al. 2012).

Academic research and crowdsourcing were equally important in building FracTracker's knowledge base. For instance, shortly after FracTracker's founding, the Pennsylvania Department of Environmental Protection (DEP) began posting limited datasets relevant to UOGD, such as the locations of wells, on their website. The Commonwealth of Pennsylvania also began making oil and gas data publicly available on the official Pennsylvania Spatial Data Access (PASDA) website. But one needed to dig deep into these datasets to determine which pertained to unconventional drilling as opposed to the tens of thousands of conventional wells that had been drilled in the state since the turn of the century. Also of note, even though the two websites are both run by state agencies, their data did not always overlap. Once mapped by CHEC, users of the DataTool frequently ground-truthed the data to discover inaccuracies and omissions. In a reverse exchange, violations from facility inspections began to appear in the DEP's "Environment Facility Application Compliance Tracking System" (eFACTS) database, but as scanned paper documents. Users of the DataTool manually reviewed violation reports and uploaded their findings, which CHEC then analyzed for patterns.

In ensuing months, FracTracker found itself increasingly at the center of tensions about what kinds of activities were appropriate for academic researchers. FracTracker's public-facing websites put CHEC at odds with industry supporters. FracTracker's principle investigator, Dan Volz, came under attack from groups such as Energy In-Depth, a public relations news outlet supported by the Independent Petroleum Association of America. ${ }^{3}$ Volz ultimately resigned from the university, stating in newspaper interviews that he was told by campus administrators not to talk about Marcellus Shale issues and that faculty should "just do scholarly research and publish it in journals" (Malloy 2011; Fábregas 2011). ${ }^{4}$ Meanwhile, across campus, other researchers readily accepted private funding to do studies supporting industry interests (Zhang et al. 2015).

As a result of these growing political pressures, FracTracker exited the University of Pittsburgh in 2012 and reorganized as the nonprofit FracTracker Alliance. Two graduate students stayed on with the project, Samantha Malone Rubright (now FracTracker's Manager of

\footnotetext{
3 Volz had become vocal about evidence of Pittsburgh's drinking water sources being contaminated by drilling wastewater. The DEP confirmed his evidence three months later by calling on drilling operators to cease delivering liquid oil and gas waste to most of the state's water treatment facilities.

4 This is one of a number of examples where the oil and gas industry pushed critical academics out of universities. For more details on this unfortunate trend see the Public Accountability Initiative report (2015) "Freedom Fracked?"
} 
Communications \& Partnerships) and Kyle Ferrar (now FracTracker's Western Program Coordinator), as did CHEC's GIS specialist, Matt Kelso (now FracTracker's Manager of Data and Technology). The organization brought on an executive director, formerly the Manager of Education and Outreach at the Pennsylvania Department of Conservation and Natural Resources. Funding was secured from private foundations to hire additional staff in Ohio and New York with backgrounds in environmental planning, ecology, biochemistry, and geography. Expanded capacity provided new opportunities to work with partners across the country on a wider range of issues. FracTracker also retired the DataTool and the staff blog in favor of an ArcGIS-based mapping platform integrated into a relaunched FracTracker.org website with expanded digital storytelling features.

These decisions came out of a series of user studies that showed FracTracker's in-house research to obtain, map, and synthesize data overwhelmingly increased respondents' knowledge of UOGD risks, but that only a fraction of people continued to use FracTracker's data uploading and manipulation features. Datasets became more complex and users increasingly came to rely on FracTracker to make sense of the data (Malone et al. 2012). FracTracker Alliance, thus, shifted from an information transparency research project into a full-fledged technical service provider with the mission of assisting civil society groups, reporters, and academic researchers in their efforts to understand the UOGD industry.

\section{Civic Informatics}

FracTracker's story parallels the neoliberal transformation of academic institutions seen in recent decades (Lave 2012; Kleinman and Vallas 2001) that have normalized "undone science" in society, or "areas of research that are left unfunded, incomplete, or generally ignored but that social movements or civil society organizations often identify as worthy of more research" (Frickel et al. 2009 , 444). Hess (2016) argues that civil society organizations contend with the issue of undone science in a variety of ways, such as by identifying knowledge gaps and generating independent research to fill those gaps. Indeed, many STS scholars have demonstrated that civil society groups are capable of sophisticated levels of independent engagements with scientific research (Ottinger 2009; P. Brown 2007; Irwin 2002; McCormick 2009; Epstein 1996; Wynne 1996). An integral part of this history includes building alliances with sympathetic researchers in academic and government institutions; relationships bound by a common goal of doing ethical science that Fortun and Fortun (2005) characterize as "civic science." However, as seen in FracTracker's evolution, universities are quick to shut down research critical of powerful industries, thus 
deepening voids of professional support that must be filled by civil society research organizations and technical service providers.

Changing relationships between the academy and concerned publics create new barriers to responsible science, but also offer strategic opportunities to transform public-minded science. On the one hand, Ruppert $(2015,138)$ observes in her studies of technical service providers in egovernance projects that, "while wresting facts from experts and putting them in the hands of data publics, specific kinds of 'technical capital'—skills, resources, and knowledge-are required to design and mobilise the necessary material, social and literary technologies." In trying to do science for public good, mediators can become the new gatekeepers when connecting information to lived experiences (Mazzarella 2004; Mazzarella 2006; Verbeek 2006). On the other hand, the material, social, and literary technologies of civic science can build on the politics of critical design and participatory action research to radically alter dynamics of power; relationships explored in Wylie et al.'s (2014) writings on civic technoscience. These possibilities generate a number of questions that we explore in the remainder of this paper. In studying civil society organizations that fill gaps created by reluctant academic institutions, we ask: How do their informational practices define research agendas in civic science? In what ways do they shape public interactions with academia, industry, and regulators? And, ultimately, how does their work afford new opportunities for political action?

FracTracker Alliance's mission is platformed on the argument that accessible and actionable data increases the empowerment capacity (Corbett and Keller 2005) of citizens to participate in environmental governance. In this sense, FracTracker is familiar to studies of informatics in social movements that have addressed issues in government transparency and data activism. Robinson et al. (2009) observe how "third party data processing" of government data encourages new ways of working with data, such as by making data mashups, establishing discussion forums, and building resource pages with links to data's sources. Bertot et al. (2014) argue that these are important tools for communities when engaging with the complexity of data as it becomes ubiquitous in how citizens interact with government. Meanwhile studies in data activism highlight expressions of action (Milan 2015)-- “'the tactics, identities, and modes of organizing" (Milan and Velden 2016) within political movements that advocate for data transparency. Schrock $(2016,581)$ suggests that data activism is fundamentally a movement of "crafting of algorithmic power and discussing ethics of technology design."

In this paper, we propose that the data practices of civic science are unique in that they tend to bring the radical politics of data activism and the practicality of government transparency initiatives under one roof. In addition to pushing back against regimes of imperceptibility, a 
"civic informatics" is enacted through research projects aimed more at getting undone science done than simply getting data into the hands of more people. This lens of civic informatics brings additional attention to the intermediaries that facilitate civic science knowledge flows, as well as to how those flows create recursive opportunities for inquiry and critique. The following case studies illustrate these distinct characteristics in different ways.

\section{Three Enactments of Civic Informatics}

\section{Mapping Municipal Movements Against Hydraulic Fracturing}

In 2007, residents in southern and central New York received visits and letters from oil and gas industry representatives expressing interest in leasing their mineral rights. Residents were also invited to free dinners in an effort to cultivate relationships with communities. Many areas of New York, particularly in the rural western counties, had previously been leased for conventional oil and gas exploration, but this new push to obtain mineral rights was far more aggressive. Although UOGD was already quite common in Pennsylvania, New York landowners were illinformed about the differences in drilling techniques. They signed leases, often without consulting attorneys, and found themselves locked into agreements that gave companies an open license to build access roads, pipelines, and waste storage tanks on their properties (Urbina and McGinty 2011). Not long after the wave of lease signing, seismic "thumper" trucks arrived. Helicopters were regularly seen delivering sensing equipment to scan for mineral deposits. A mixture of curiosity and alarm prompted residents and elected officials to research what this new type of energy exploration might bring to their communities.

Permitting for oil and gas exploration in New York was already covered by a Generic Environmental Impact Statement (GEIS) outlined in 1992. However, the New York Department of Environmental Conservation (DEC) felt that the GEIS should be updated before allowing companies to proceed with unconventional drilling. A temporary statewide unconventional drilling moratorium was imposed and, in 2009, the agency issued the first of several Draft Supplemental Generic Environmental Impact Statements (D-SGEIS) (New York State Department of Environmental Conservation 2015). A vigorous public review of the document commenced. Citizen's coalitions, such as New Yorkers Against Fracking, brought forth research and case studies from Pennsylvania, Texas, Colorado, and Wyoming to question the safety of the industry's practices (New Yorkers Against Fracking 2015). Among other provisions, the D-SGEIS evolved to include more stringent safeguards and excluded New York City's extensive up-state source waters from drilling activity. Despite these gains, communities in rural areas protested 
their being designated a "sacrifice zone" and felt they deserved equal protections in the event the statewide moratorium was lifted (Figure 1).

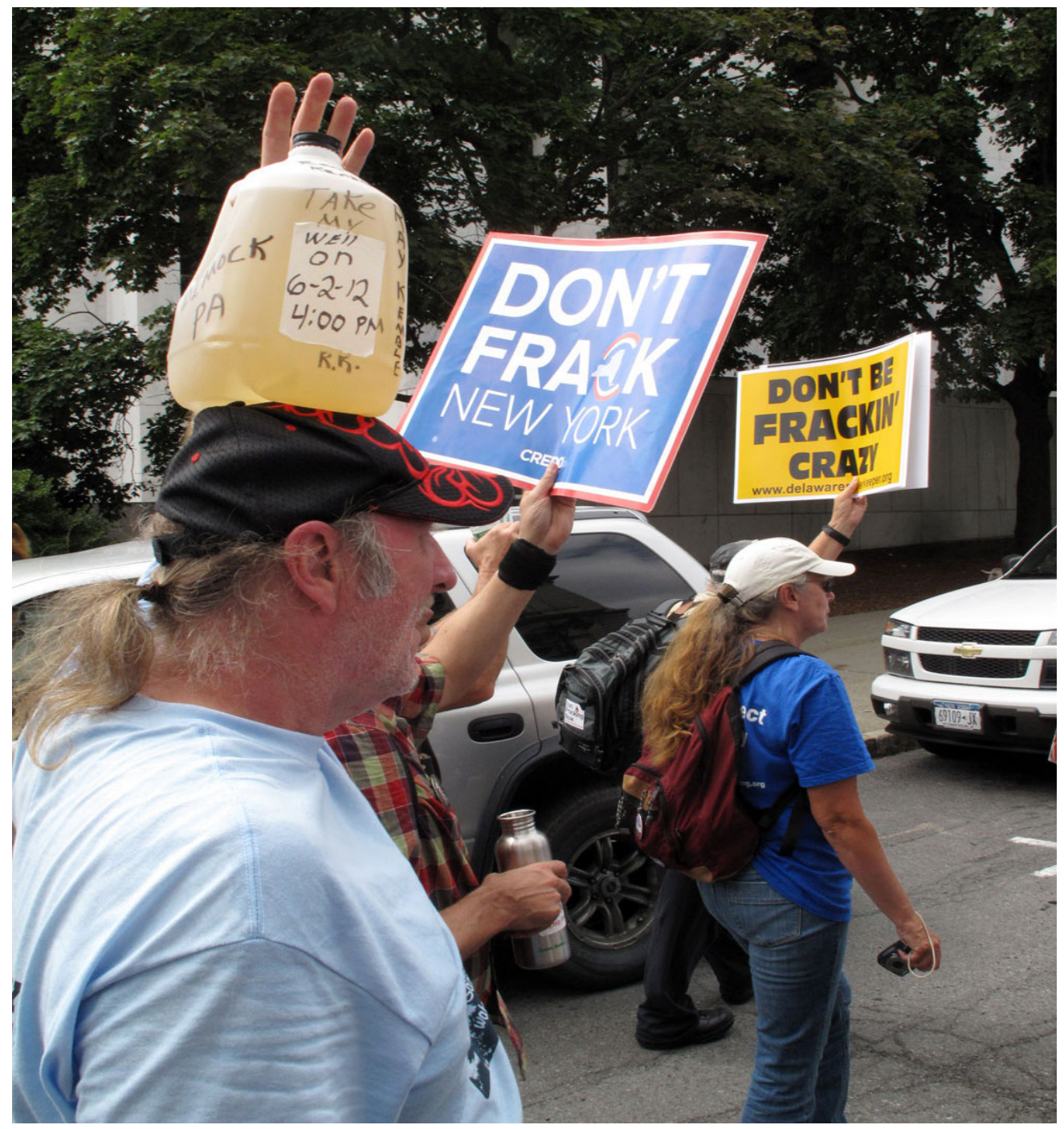

Figure 1: Protestors rally for a ban in Albany, New York (photo by authors).

Local land use statutes in New York are determined by "home rule," where individual municipalities have the power to make zoning and development decisions within their political boundaries. In 2011, several municipalities used home rule laws to pass drilling bans and moratoria (Simonelli 2014). Local governments justified their decisions by citing the potential for 
water supply contamination, excessive truck traffic and likely road damage, as well as public health risks in residential neighborhoods (Northrup 2014). It was at about this time that FracTracker's Eastern Program Coordinator, Karen Edelstein, who lived in Ithaca, New York, was asked to develop a simple map to support a group of attorneys and activists doing D-SGEIS public education programs. FracTracker's map was a simple snapshot of municipalities that had adopted or were in the process of approving drilling restrictions. Once concerned citizen groups realized that home rule could be used to prohibit drilling, local and statewide advocacy listservs boiled over with discussions of how to duplicate the tactic in other municipalities. Edelstein responded by building an interactive bans and moratoria map (Figure 2) for publicly tracking successfully passed legislation (Edelstein 2016). A new "movements" category was later added to denote emerging efforts in different communities. The map was shared widely and used as a tool in local campaigns. Frequent communications from users included comments such as, "Our town board meeting is next week and I hope to present the updated map as a visual aid to one board member's presentation of reasons for a ban."

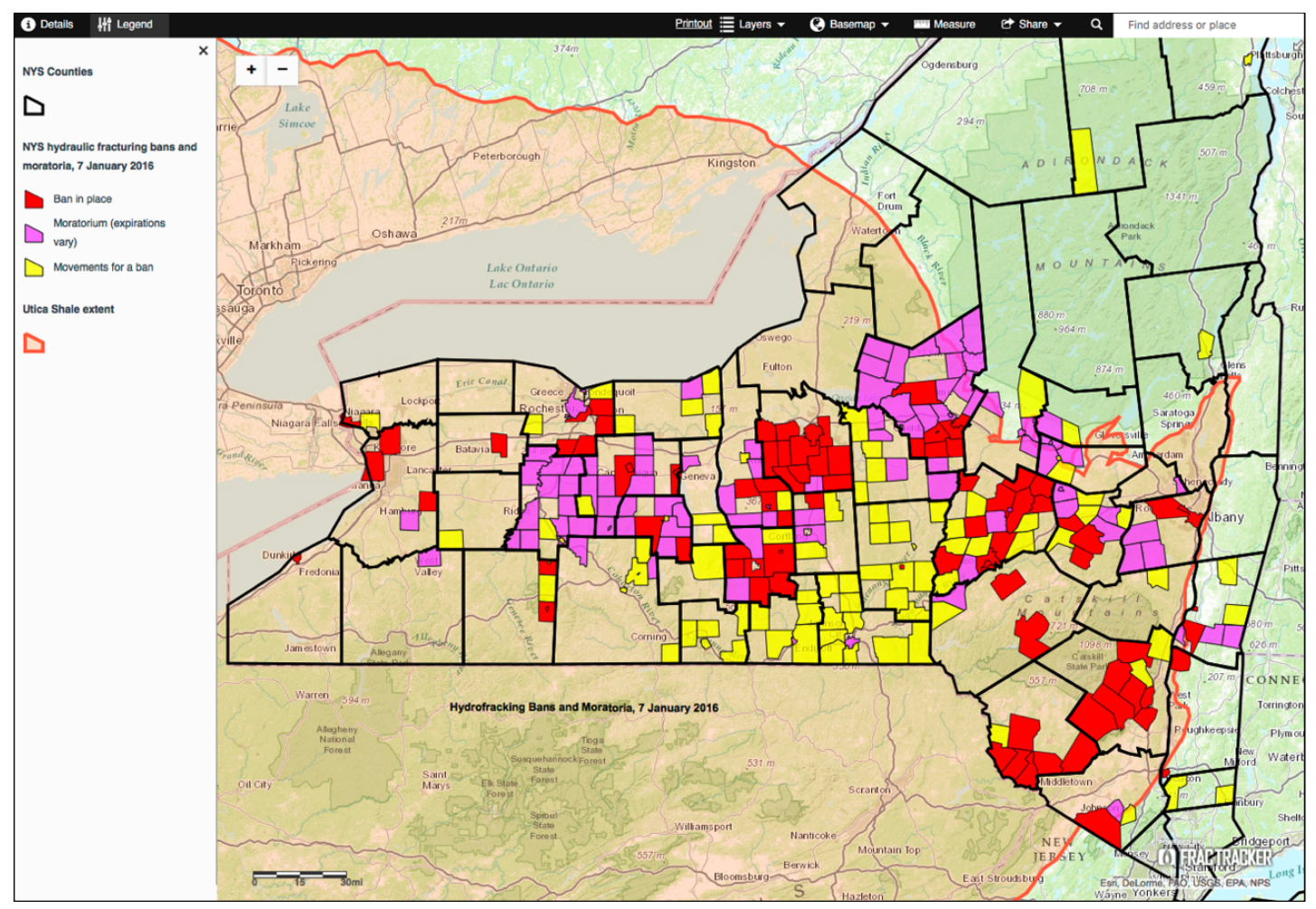

Figure 2: Screenshot of New York bans and moratoria; map last updated January 7, 2016. 
Maintaining the map was a highly collaborative process. While, in some instances, FracTracker discovered new legislation in news articles and other sources, more often than not updates came in the way of emails from local residents. One stated: "Could you please add Berkshire to the map of NY towns with a 'movement toward a ban or moratorium?' Whether we get it or not, we want people to know we're trying!" Another offered "Can you please add Truxton, in Cortland County, NY, to the map for towns working for a ban or moratorium. It's very encouraging to see all the towns doing this and succeeding!" Edelstein made it a priority to respond to these requests within 48 hours. Between 2012 and 2014, FracTracker generated more than fifty editions of the online bans and moratoria map, along with extensive summaries and written analysis.

The New York local bans and moratoria movement continued to build momentum. By the end of 2014, 90 local bans and 92 local moratoria had been enacted, including resolutions in the major cities of Buffalo, Rochester, Syracuse, Binghamton, Utica, and Albany. In December 2014, New York's Governor Cuomo, the DEC Commissioner, and the New York Commissioner of Health announced that, after nearly seven years of studies and public comment, oil and gas drilling operations that utilize high-volume hydraulic fracturing (HVHF) would not be allowed in the state (New York State Department of Health 2014). Among other pieces of evidence presented in the cabinet meeting, the DEC Commissioner cited FracTracker's map as indication of strong statewide opposition to HVHF, stating in his testimony:

\footnotetext{
According to the Joint Landowners Coalition, many towns in the Southern Tier have passed resolutions favoring HVHF, while the online map from FracTracker.org indicates that many of the same towns are moving toward a ban. Indeed, our own informal outreach to towns in the Southern Tier confirms that even towns that support HVHF decisions are still up in the air. I'd say that the prospects for HVHF development in New York are uncertain, at best (New York State Office of the Governor 2014).
}

On the surface, these activities might appear typical to an environmental movement, but the function of FracTracker's bans and moratoria maps are an example of how technical service providers play an important role in civic informatics. FracTracker's mapping made visible the extent to which an otherwise dispersed community of residents had come to understand the risks of UOGD and demonstrated the strength of their political opposition. It did so through a recursive process of sharing and vetting information. Residents used the maps as leverage to convince municipal leaders of the credibility of the bans movement. In turn, their successes 
encouraged residents in other municipalities to similarly challenge the oil and gas industry. FracTracker staff facilitated these knowledge flows, but the map's power hinged on advocacy leaders working with FracTracker to keep up to date on pending legislation, upcoming meetings, and successful votes. NGOs that worked with citizen groups also consulted with FracTracker to check the accuracy of the maps when using them in their campaigns. Realizing the significance of mapping bans and moratoria, FracTracker has gone on to develop similar resources for movements fighting other UOGD projects spread across large geographies, such as pipelines (Edelstein 2014b; Edelstein 2015).

\section{Tracking the Threats of Crude Oil Trains}

The increasingly common practice of transporting crude oil on railways from the Bakken shale formations of North Dakota to other points in the United States poses what many feel is a significant public health risk. A typical trainload can carry more than 100 cars, containing as much as three million gallons of crude oil (Starbuck 2015). Crude oil trains often travel through highly populated cities, near major drinking water sources, and pass by sensitive public infrastructures such a schools and hospitals. Bakken crude is also far more volatile than typical crude oil, which has led to a rise in railway disasters. Major derailments and explosions have occurred in Casselton, North Dakota; Lynchburg, Virginia; Pickens County, Alabama; and Mount Carbon, West Virginia (Hudson Riverkeeper 2017). The deadliest disaster occurred in 2013 when a train derailed in the town of Lac-Mégantic, Quebec Province, Canada, killing 47 people and destroying more than 30 buildings (Transportation Safety Board of Canada 2014; Brisson and Bouchard-Bastien 2017).

Problems of railway safety and oversight gained national attention due to the high-profile accidents noted above, but also because of poor government transparency on the issue. The US Department of Transportation (DOT) ruled in 2014 that crude oil trains constitute "an imminent hazard" and required rail carriers to notify state-level emergency response centers when transporting more than one million gallons (United States Department of Transportation 2014). Nevertheless, very little information on the volumes, routes, and destinations of crude oil trains is available to the public (Tate 2015). Following the 9/11 terrorist attacks and the formation of the Transportation Security Administration, new federal rules limited transit information disclosures for high-risk commodities such as radioactive material, explosives, and volatile liquids (United States Department of Transportation 2011). While crude oil does not explicitly fall within these 
classifications, government agencies and rail carriers have conservatively interpreted DOT's rules.

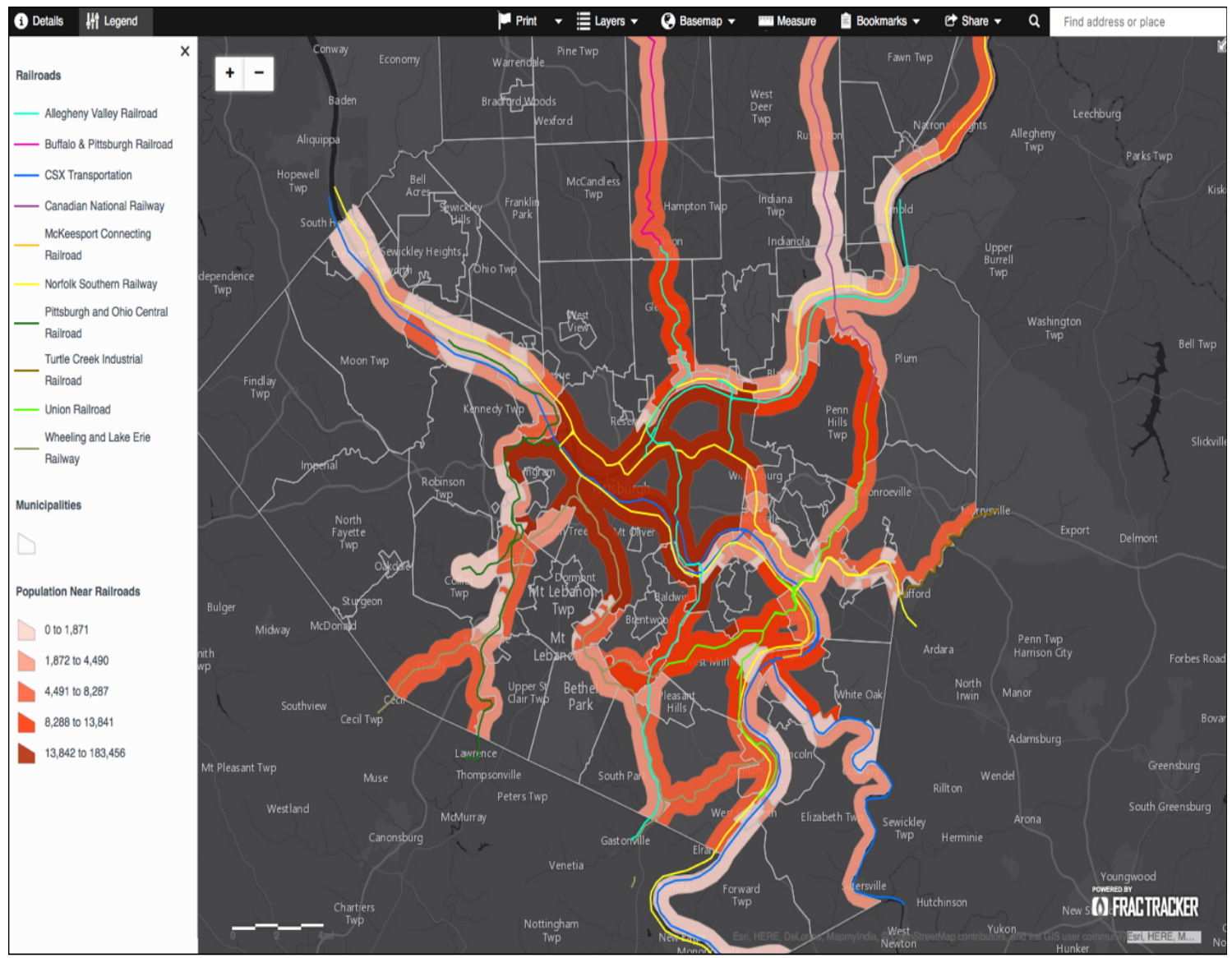

Figure 3: Screenshot of populations near crude oil train routes in Allegheny County, Pennsylvania.

FracTracker Alliance began working on crude oil train issues in August of 2014 at the request of regional NGO partners. Matt Kelso, FracTracker's Manager of Data and Technology, began by obtaining data on train accidents from the Federal Railroad Administration, then mapping these with data layers representing the nation's railways and locations of oil refineries. The DOT's Emergency Response Guidebook requires a standard half-mile evacuation radius for railway accidents involving flammable liquids. This extends to one mile in the event that those materials are on fire (United States Department of Transportation 2012). Bringing this information 
together, FracTracker proceeded to identify at-risk populations and sensitive infrastructure along railway routes known to carry Bakken crude oil.

FracTracker's analysis of routes in western New York State found that more than 86,000 people and 24 schools were within the half-mile evacuation zone in the city of Buffalo. Nearly 60,000 people and 20 schools resided within the half-mile zone in the city of Rochester (Edelstein 2014a). Extending this analysis to the entirety of Pennsylvania in 2015, FracTracker determined that more than 3.9 million residents in the state lived within evacuation zones for a crude oil train accident, with the cities of Philadelphia (709,869 residents) and Pittsburgh (183,456 residents) topping the list (Malone-Rubright 2015). These studies were made available through FracTracker's website, accompanied by interactive railway maps that allowed users to zoom in on municipalities, identify the names of schools, and view population densities within potential evacuation zones (Figure 3).

FracTracker's assessment of Pennsylvania's crude oil train risks ultimately contributed to a whitepaper published by the PennEnvironment Research \& Policy Center, a statewide environmental advocacy organization (Masur et al. 2015). The report gained broad media attention (Moore 2015; Khan and Kanik 2015) and contributed to pressuring the Governor's office to authorize a 27-point document of mandated safety improvements for railway operators and regional emergency planning office in August 2015 (Pennsylvania Office of the Governor 2015).

While the PennEnvironment whitepaper sought to improve regulatory oversight, many residents remained unaware of when and where crude oil trains passed through their communities. This disconnect made it challenging for people to understand their personal risks and how they might take action to support changes in crude oil shipping practices. Recognizing that one way to connect local understanding to action is through community-based participatory research, FracTracker Alliance partnered with Carnegie Mellon University's CREATE Lab (Community Robotics, Education and Technology Empowerment Lab) to develop the Crude by Rail Train Count Project. Using clipboards, and later video recording equipment, volunteers sighted hazmat placards on train cars and noted how many they identified as \#1267, denoting crude oil, or \#1075, denoting liquefied petroleum gas (Hopey 2015; Malone-Rubright and Kelso 2014).

The project was launched in July, 2015, at two sites in Pittsburgh, two sites in Philadelphia, and one site in Harrisburg, Pennsylvania, over two consecutive days. Volunteers were stationed at each site in shifts, from 8am to 8pm (Figure 4). Volunteers counted 3,107 train cars, of which 185 contained either crude oil or liquefied petroleum gas-equaling as much as six million gallons. Volunteers noticed how some trains stopped for lengthy periods of time in 
densely populated neighborhoods, whereas others passed by at unsafe speeds. They also noted flammable placards with different numbers they wanted to know more about. Since the initial roll-out, FracTracker has received numerous reports from community groups who have used the protocols. In one instance, a group spent nine days counting trains in the remote Donner Pass canyon region of the Sierra Nevada Mountains, through which Bakken crude travels on its way to refineries north of Oakland, California. In an email to FracTracker they commented, "we know much more about trains and railroads as a result of the watch and count."

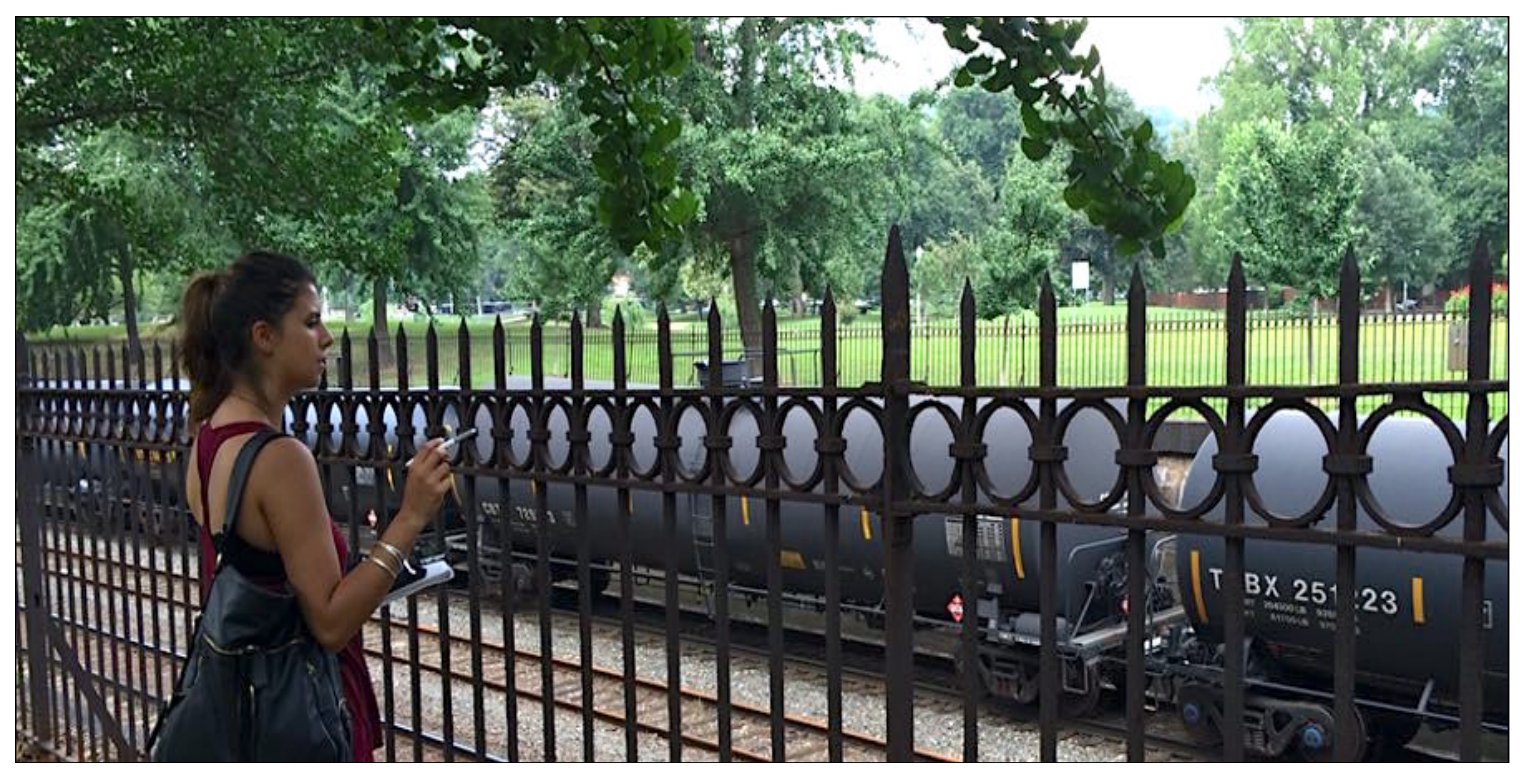

Figure 4: Counting crude oil trains in Pittsburgh, Pennsylvania (photo by the authors).

These stories and other findings from FracTracker's crude oil train research were brought to a broad group of stakeholders in November, 2015, at the National Oil Train Response Summit in Pittsburgh, Pennsylvania, convened by FracTracker Alliance in partnership with the national NGO ForestEthics (now called Stand) and funded by the Heinz Endowments. Over 200 representatives from governmental agencies, concerned citizen groups, and NGOs from across the US, Canada, and First Nations participated in discussions and educational training workshops. Three national listservs and several active working groups are a few of the outcomes that resulted from this initiative. Conference participant groups have also begun to add their efforts to the "Alliance Map," another FracTracker initiative that keeps track of advocacy efforts working on UOGD issues so they can more easily coordinate activities. 
FracTracker's work on crude oil trains illustrates an additional dimension of civic informatics. By encouraging limited public disclosure of railway information, crude oil shippers operate in a liminal space where proper oversight is assumed but not fully known. Macro-level understanding of oil and gas infrastructure is thus retained as the exclusive domain of industry and regulatory agencies. FracTracker's railway maps and visualizations of communities at risk revealed the geographies and systemic dangers of crude oil trains. Meanwhile, the Train Count Project encouraged people to spend time near the tracks and see crude oil trains first-hand. This exemplifies how civic informatics can be an expression of professional expertise and communitybased expertise coming together to identify knowledge gaps and mobilizing data to push back against regimes of imperceptibility.

\section{Communicating Civic Science through Digital Storytelling}

UOGD introduces new challenges to understanding the health of watersheds in extraction communities where spills at drilling sites, damaged well casings, trucking accidents, and other potential sources of pollution can find their way into nearby streams, rivers, and lakes (Brantley et al. 2014; Rich and Crosby 2013). In many instances the effects of these impacts remain unknown due to inadequate regulatory monitoring and inspection programs. Beginning in 2010, a number of capacity building organizations developed monitoring protocols to assist residents across the Marcellus Shale in measuring basic water quality indicators near UOGD activity. Training programs were established to propagate standard practices and to build up larger monitoring networks (Jalbert, Kinchy, and Perry 2014; Kinchy and Perry 2012; Jalbert 2016).

The many volunteers who participate in these efforts were collecting extensive baseline data to better understand the health of their communities. However, watershed scientists and regulators remained reluctant to recognize the contributions that volunteer monitoring might offer to public discussions on the health of natural resources (Kinchy, Jalbert, and Lyons 2014). Meanwhile, communities and funders interested in watershed management were often unaware of volunteer monitoring occurring in their own backyards.

In 2013, more than twenty monitoring groups and capacity building organizations convened in Pittsburgh, Pennsylvania, with the objective of increasing public understanding of their programs. Kirk Jalbert, who was completing his dissertation on the Marcellus Shale monitoring community while then a visiting researcher with FracTracker, was one of the participants. Among other outcomes of the meetings was an agreement to share the locations where monitoring groups were collecting data. While many of the groups tracked this 
information internally, sharing geolocation data was historically considered risky due to fears about revealing the identity of their volunteers and putting them in danger while field sampling. The coordinator group also deemed it important to cultivate public outreach materials to share the stories of volunteers, with the hope that broader awareness of their work might enlist additional volunteers, funders, and regulatory acceptance of data. Jalbert suggested FracTracker Alliance as an appropriate partner for generating and hosting this content and, in 2014, the "Knowing Our Waters" project was launched with financial support from a private foundation (Jalbert 2014).

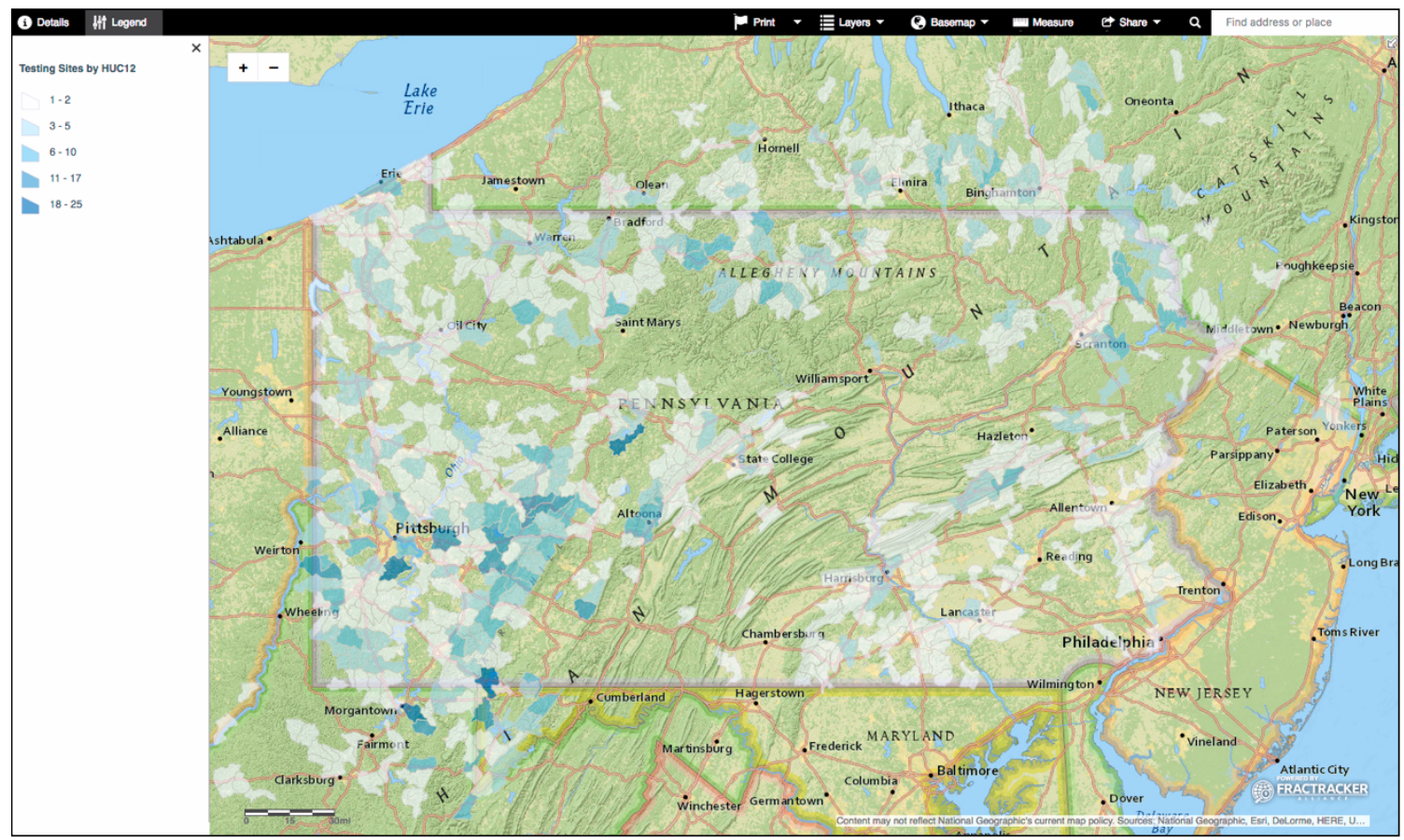

Figure 5: The Knowing Our Waters map of watersheds monitored by volunteers.

Knowing Our Waters was FracTracker's first foray into the world of digital storytelling, which brought together interviews with volunteers, interactive maps, data interpretations, and articles co-produced with different monitoring groups. Other resources developed in the project included directories of the more than 50 monitoring efforts in the Marcellus Shale, along with details on their methods. An interactive map was published identifying which watersheds were being monitored by volunteers in New York, Pennsylvania, West Virginia, Maryland, and Ohio (Figure 5). Mapping the watersheds where monitoring was occurring, rather than the precise 
monitoring locations, highlighted areas in need of additional attention while still protecting the volunteers' identities.

One of several articles in the Knowing Our Waters series highlighted the monitoring efforts of the Izaak Walton League of America's (IWLA) Harry Enstrom Chapter, a sporting advocacy group located in Southwestern Pennsylvania's Greene County. Greene County produces over $12 \%$ of the underground mined coal tonnage in the US and is also the third most drilled county for unconventional oil and gas in Pennsylvania (Center for Coalfield Justice 2014). Through their monitoring, IWLA volunteers discovered high levels of bromide (an indicator of hydraulic fracturing wastewater) at five of their sampling sites. In each case, these sites were outflows of coal slurry holding ponds, leading watershed scientists at West Virginia University to suspect waste products from coal mining and UOGD had co-mingled in underground mine shafts or in refuse impoundments managed by the coal industry (Khan 2013).

In order to communicate this story, Kirk Jalbert joined the IWLA on a tour of their monitoring locations. Using ethnographic methods familiar to STS, Jalbert conducted video interviews with IWLA chapter members, documenting their techniques and motivations. In follow-up meetings, Jalbert consulted with chapter members to summarize their data and rifle through reports IWLA had received from the DEP and other sources. This content came together in a Knowing Our Waters article detailing IWLA's sampling sites (Figure 6) and watershed protection objectives in Greene County (Jalbert 2015).

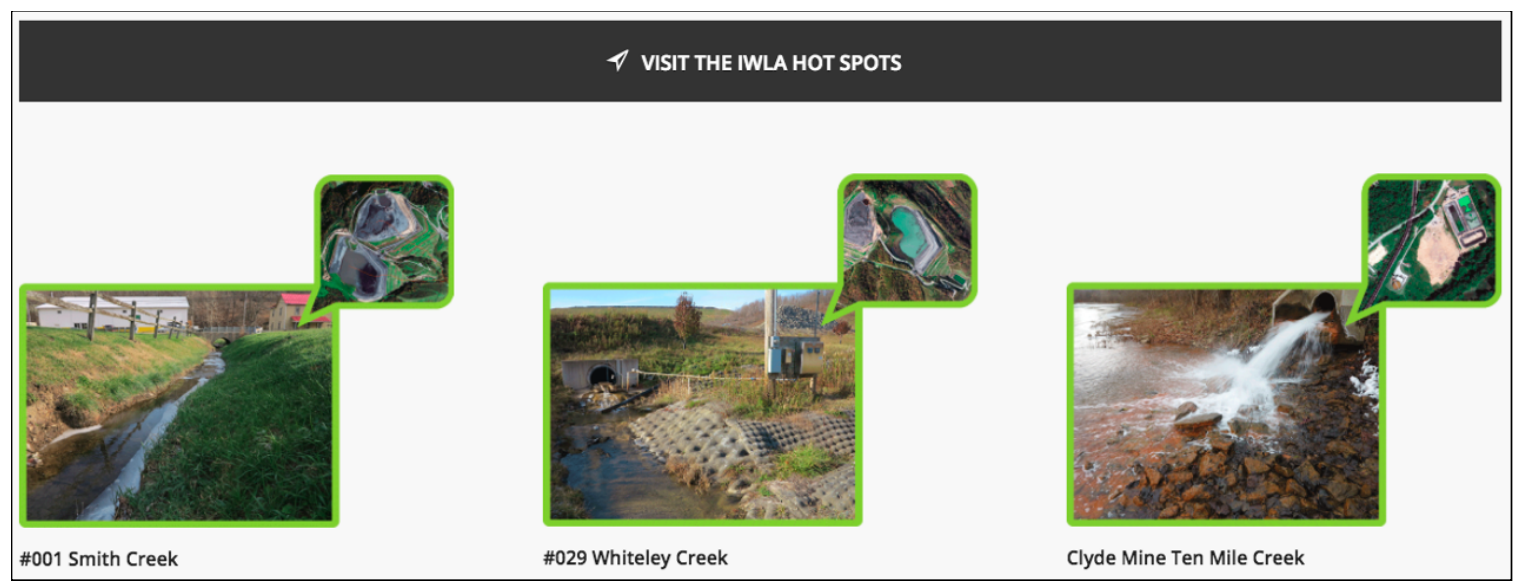

Figure 6: Knowing Our Water tools for virtually touring the IWLA's monitoring sites.

This final case study illustrates how mediators can avoid the problem of inadvertently becoming gatekeepers in civic science. Knowing Our Waters brought attention to how UOGD's 
risks united people to become scientists and participate in environmental debates. However, it did so by creating a platform for monitoring groups to communicate their own science and narratives, rather than FracTracker simply writing on behalf of their work. The IWLA article has since gone on to be published in other places such as in Shalefield Stories, a collection of firsthand testimonies from people living in extraction communities. Proceeds from Shalefield Stories have raised more than $\$ 25,000$ to fund drinking water distribution, home air purifiers, and monitoring equipment (Friends of the Harmed 2017). Critical GIS researchers Corbett and Keller $(2005,28)$ make a distinction between empowerment-“a tangible increase in social influence or political power"-and empowerment capacity-"aspects of the deeper process of change in the internal condition of an individual or community that influence their empowerment." Civic informatics projects like Knowing Our Waters have the potential to build the empowerment capacity of communities in this way.

\section{Discussion}

FracTracker's exit from the University of Pittsburgh freed its researchers to engage in politically sensitive work. The project's transition into the civic science community also brought new kinds of labor. In addition to the tasks of obtaining, analyzing, and mapping data, staff increasingly worked in broad coalitions to mobilize data in political, environmental, and public health related campaigns. Today, FracTracker Alliance hosts more than 100 maps, 900 data layers, and nearly 600 pages of commentary and analysis. A significant portion of this content was developed in partnerships similar to those seen in the case studies offered here. FracTracker's projects are

driven by the logic that mobilizing data can facilitate public participation in environmental governance. FracTracker's role in civic science is, therefore, to increase informational flows and to develop more nuanced uses of data in collaborative research. These activities are emblematic of practices that we've termed civic informatics, where civic informatics is less concerned with making data transparent-for-transparency-sake than it is with using data to simultaneously advance science and advocacy.

State and federal laws that manage UOGD limit awareness through poor commitments to government transparency, such as is seen in histories of how information on well sites, regulatory violations, train routes, and other data were made public. Meanwhile, industry has fought hard through lobbying and public relations campaigns to avoid scrutiny and remain exempt from environmental protection laws. These opacities allow the oil and gas industry to take strategic positions across large geographic areas and develop tactics to discredit critics and infiltrate 
resistant communities. Civic informatics, first and foremost, wrestles with these regimes of imperceptibility (Murphy 2004). Organizations like FracTracker Alliance reveal the systemic nature of the industry and builds capacity for dispersed stakeholders to question its practices. This is most evident in FracTracker's research on crude oil trains. Mapping known shipping routes and at-risk communities offered a glimpse into the dangers of oil trains that state and federal agencies had known of all along. In tandem, the Train Count Project connected general assessments of risk to sites where risk is experienced.

Another characteristic of civic informatics is the scaffolding of knowledge that occurs as more people are drawn into the process of public inquiry. FracTracker's mapping of local bans and moratoria in New York State made visible the extent to which communities opposed highvolume hydraulic fracturing. While the first map was made in response to a single request, subsequent versions of the map became iconic graphics referenced with great regularity by the media and in municipal planning meetings. The "movements" data layer was particularly effective in legitimizing grassroots organizations. Registering their legislative successes in public view encouraged other communities to follow suit. Leading up to the Governor's cabinet meeting, one community leader reached out about the map in saying, "It's a beautiful sight, like the spring flowers popping out all over," which we felt was highly symbolic of this scaffolding process.

Over the course of building capacity to understand UOGD in many different projects, we have learned a number of important lessons about what it means to work as mediators. First, newly revealed information always spawns fresh inquiries and demands for more information. As Ruppert (2015) observes, "enacting the transparent state" is not a singularly defined event but an ever-unfolding process. Relationships between available data, invested stakeholders, and the need for knowledge are in constant flux. Second, we find that the "making and doing" of civic informatics is similarly an iterative process; one of verifying, interpreting, and mobilizing information in diverse and deeply rewarding partnerships.

In order to maintain full transparency, and to ensure long-term public engagements, we feel that, as researchers, it is also important to recognize the inherent uncertainty of data and to appreciate the power dynamics involved when working with diverse publics. Mazzarella (2006) observes, "the will to transparency has a tendency to reproduce opacity. But, by the same token, the pursuit of immediation also has the potential to render visible its own conditions of possibility-the tremendously complex and always contestable terms of mediation upon which contemporary polities and informational networks rely." FracTracker's recent experimentations with participatory digital storytelling, as seen in projects such as Knowing Our Waters, are 
designed to push us farther out on this sometimes-uncomfortable limb of relinquishing control over the narratives of research.

In conclusion, FracTracker's trajectory is indicative of the recent turn in science where academically-trained researchers seek out non-institutional spaces-voluntarily or otherwisethat bring together praxis and theory, community-based expertise and professional expertise, in order to make meaningful interventions in society. Our primary argument in this paper has been that FracTracker Alliance is attuned to the needs of a concerned public precisely because of its centrality within these spaces of critical inquiry. FracTracker's mapping of bans and moratoria, tracking of oil trains, and building of tools for citizen scientists to advocate for their science would likely not have been possible if done from its prior position at the University of Pittsburgh - partly due to the work's highly political implications, but also because this kind of research is not valued as groundbreaking or fundable, despite its demonstrated importance. Nevertheless, FracTracker's continuing commitments to prioritize research over advocacy makes it possible for the organization to partner across broad groups of stakeholders, including citizen coalitions, academic researchers, news outlets, NGOs, and government officials.

While the history of FracTracker Alliance should not be taken as proof of success in overcoming the difficulties of undone science, it does offer evidence that researchers can effectively pursue their interests outside the walls of academia. Indeed, many of the individuals we interact with come from backgrounds familiar with critical discourses in feminist geography, popular epidemiology, and social studies of science, and employ them in their work. By identifying the nature of their reflexivity in the everyday practices, in the "making and doing" of science, we believe there are vast opportunities for enhancing scholarly commitments to publicminded research.

\section{Author Biography}

Kirk Jalbert is the Manager of Community-Based Research \& Engagement at the FracTracker Alliance, as well as a Visiting Research Professor at Drexel University's Center for Science, Technology \& Society. Jalbert also serves on the Pennsylvania Department of Environmental Protection's Environmental Justice Advisory Board. His research seeks to understand civic engagements in environmental governance that are enabled by information technology projects. Jalbert received his PhD in Science and Technology Studies from Rensselaer Polytechnic Institute, has a MFA in media arts, and a BS in computer science. 


\section{Author Biography}

Samantha Rubright is the Manager of Communications and Partnerships for FracTracker Alliance. Dr. Rubright obtained her Certification in Public Health (CPH) and Doctor of Public Health (DrPH) from the University of Pittsburgh Graduate School of Public Health's Environmental and Occupational Health Department, focusing on the effects of exposure to cyanide and hydrogen sulfide. Additionally, she has worked in Africa and Europe, exploring and advising on the impacts of extractive industries on communities and public health.

\section{Author Biography}

Karen Edelstein is the East Coast staffer for the FracTracker Alliance. She creates maps to highlight impacts of fossil fuel extraction and movements in opposition to oil and gas infrastructure, as well as celebrate successes of communities turning to renewable energy. Karen has an extensive background in natural history and ecology, and holds a MPS in Environmental Management from Cornell University.

\section{Acknowledgements}

We wish to thank Matthew Kelso, Manager of Data \& Technology of FracTracker Alliance, for his data analysis and mapping work supporting many of the projects mentioned herein. We also wish to thank the funders who have supported these projects including The Heinz Endowments, Colcom Foundation, and Park Foundation. Foundational research supporting the Knowing Our Waters project was also funded in part by a National Science Foundation Doctoral Dissertation Improvement Grant (NSF \#1331080) from the Directorate for Social, Behavioral and Economic Sciences.

\section{References}

Brantley, S.L., D. Yoxtheimer, S. Arjmand, P. Grieve, R. Vidic, J. Pollak, G.T. Llewellyn, J. Abad, and C. Simon. 2014. "Water Resource Impacts during Unconventional Shale Gas Development: The Pennsylvania Experience." International Journal of Coal Geology 126 (6). Elsevier B.V.: 140-156. doi:10.1016/j.coal.2013.12.017. 
Bertot, J.C., U. Gorham, P.T. Jaeger, L.C. Sarin, and H. Choi. 2014. "Big Data, Open Government and E-Government: Issues, Policies and Recommendations." Information Polity 19: 5-16. doi: $10.3233 /$ IP-140328.

Brisson, G., and E. Bouchard-Bastien. 2017. “With or Without Railway? Post-Catastrophe of Risk and Development in Lac-Mégantic, Québec." In ExtrACTION: Impacts, Engagements, and Alternative Futures, edited by Kirk Jalbert, Anna Willow, David Casagrande, and Stephanie Paladino, 123-136. London / New York: Routledge.

Brown, D., B. Weinberger, C. Lewis, and H. Bonaparte. 2014. "Understanding Exposure from Natural Gas Drilling Puts Current Air Standards to the Test." Reviews on Environmental Health 29 (4): 277-292. doi:10.1515/ reveh-2014-0002.

Brown, P. 2007. Toxic Exposures: Contested Illnesses and the Environmental Health Movement. New York, NY: Columbia University Press.

Center for Coalfield Justice. 2014. Community Indicators of Environmental Justice: A Baseline Report Focusing on Greene and Washington Counties, Pennsylvania. Accessed 27 July 2015. https:// static1.squarespace.com/static/569fc3a70e4c11ec47ad30b1/t/57d7e4812e69cf40207d905e/ 1473766566100/Community-Indicators-Environmental-Justice-2014.pdf.

Cooley, R., and D. Casagrande. 2017. "Marcellus Shale as Golden Goose." In ExtrACTION: Impacts, Engagements, and Alternative Futures, edited by Kirk Jalbert, Anna Willow, David Casagrande, and Stephanie Paladino, 46-60. London / New York: Routledge.

Corbett, J. M., \& Keller, C. P. 2005. “Empowerment and Participatory Geographic Information and Multimedia Systems: Observations from Two Communities in Indonesia." Information Technologies and International Development 2 (2): 25-44.

Dundon, L.A., M. Abkowitz, and J. Camp. 2015. "The Real Value of FracFocus as a Regulatory Tool: A National Survey of State Regulators." Energy Policy 87. Elsevier: 496-504. doi: 10.1016/j.enpol.2015.09.031.

Edelstein, K. 2014a. "Off the Rails: Risks of Crude Oil Transportation by Freight in NY State and Beyond." FracTracker Alliance. Pittsburgh, PA. Accessed 11 January 2016. http:// www.fractracker.org/2014/09/off-the-rails/.

Edelstein, K. 2014b. "Resistance Mounts to Pipeline Across Massachusetts and New Hampshire." FracTracker Alliance, December 18. Accessed 12 January 2016. http://www.fractracker.org/ 2014/12/ resistance-mounts-pipeline/.

Edelstein, K. 2015. "A Bird's Eye View of Pipeline Oppositions." FracTracker Alliance, January 8. Accessed 12 January 2016. http:// www.fractracker.org/2015/01/pipeline-oppositions/. 
Edelstein, K. 2016. “Fracking Bans and Moratoria in NY." FracTracker Alliance, January 7. Accessed 11 January 2016. http://www.fractracker.org/map/us/new-york/moratoria/.

Epstein, S. 1996. Impure Science AIDS, Activism, and the Politics of Knowledge. Berkeley, CA: University of California Press.

Fábregas, L. 2011. "Drilling Opponent to Leave Pitt Post." Pittsburgh Tribune-Review, April 10. Accessed 11 January 2016. http://triblive.com/x/pittsburghtrib/s 731592.html axzz3vABUSyKp.

Ferrar, K.J., J. Kriesky, C.L. Christen, L.P. Marshall, S.L. Malone, R.K. Sharma, D.R. Michanowicz, and B.D. Goldstein. 2013. "Assessment and Longitudinal Analysis of Health Impacts and Stressors Perceived to Result from Unconventional Shale Gas Development in the Marcellus Shale Region." International Journal of Occupational and Environmental Health 19 (2): 104-112. doi:10.1179/2049396713Y.0000000024.

Ferrar, K.J., D.R. Michanowicz, C.L. Christen, N. Mulcahy, S.L. Malone, and R.K. Sharma. 2013. "Assessment of Effluent Contaminants from Three Facilities Discharging Marcellus Shale Wastewater to Surface Waters in Pennsylvania." Environmental Science and Technology 47 (7): 3472-3481. doi:10.1021/es301411q.

Fortun, K., and M. Fortun. 2005. "Scientific Imaginaries and Ethical Plateaus in Contemporary U.S. Toxicology." American Anthropologist 107 (1): 43-54. doi:10.1525/ aa.2005.107.1.043.

Frickel, S., S. Gibbon, J. Howard, J. Kempner, G. Ottinger, and D.J. Hess. 2009. "Undone Science: Charting Social Movement and Civil Society Challenges to Research Agenda Setting." Science, Technology \& Human Values 35 (4): 444-473. Accessed 13 September 2010. doi: $10.1177 / 0162243909345836$.

Friends of the Harmed. 2017. "Shalefield Stories." Accessed 13 July 2017. http:// www.shalefieldstories.org/.

Hays, J., and S.B.C. Shonkoff. 2016. “Toward an Understanding of the Environmental and Public Health Impacts of Unconventional Natural Gas Development: A Categorical Assessment of the Peer-Reviewed Scientific Literature, 2009-2015." PLoS ONE 11 (4): 1-13. doi:10.1371/ journal.pone.0154164.

Hess, D.J. 2016. Undone Science: Social Movements, Mobilized Publics, and Industrial Transitions. Cambridge, MA: MIT Press.

Hopey, D. 2015. "CMU, Fractraker Team up to Monitor Crude Oil Trains through Region." Pittsburgh Post-Gazette, December 13. Accessed 12 July 2017. http://powersource.postgazette.com/powersource / policy-powersource / 2014/12/13/CMU-and-Fractrackermonitor-crude-oil-trains-through-region. 
Hudson Riverkeeper. 2017. “Crude Oil Transportation: A Timeline of Failure." Accessed 11 January 2016. http://www.riverkeeper.org/campaigns/river-ecology/crude-oil-transport/ crude-oil-transportation-a-timeline-of-failure/.

Irwin, A. 2002. Citizen Science: A Study of People, Expertise and Sustainable Development. New York, NY: Routledge.

Jalbert, K. 2014. "Knowing Our Waters: Community-Based Water Monitoring in the Marcellus Shale." FracTracker Alliance, July 24. Accessed 12 January 2016. http:/ / www.fractracker.org/ projects/ water-monitor/.

Jalbert, K. 2015. "Fracking in the Coalfields: Community-Based Monitoring in Greene County, PA." FracTracker Alliance, February 18. Accessed 12 January 2016. http:// www.fractracker.org/projects / water-monitor/fracking-coalfields/.

Jalbert, K. 2016. “Building Knowledge Infrastructures for Empowerment: A Study of Grassroots Water Monitoring Networks in the Marcellus Shale." Science and Technology Studies 29 (2): $26-43$.

Jalbert, K., A.J. Kinchy, and S.L. Perry. 2014. "Civil Society Research and Marcellus Shale Natural Gas Development: Results of a Survey of Volunteer Water Monitoring Organizations." Journal of Environmental Studies and Sciences 4 (1): 78-86.

Khan, N. 2013. "Briny Water Flows into Southwestern PA Streams." PublicSource, February 13. Accessed 11 July 2017. http://archive.alleghenyfront.org/story/briny-water-flowssouthwestern-pa-streams.html.

Khan, N. 2016. "How One Resident near Fracking Got the EPA to Pay Attention to Her Air Quality." PublicSource, December 15. Accessed 11 July 2017. http://publicsource.org/howone-resident-near-fracking-got-the-epa-to-pay-attention-to-her-air-quality $/$.

Khan, N., and A. Kanik. 2015. "1.5 Million at Risk in PA for Crude Oil Derailment." NPR StateImpact Pennsylvania, March 2. Accessed 12 July 2017. https://stateimpact.npr.org/ pennsylvania/2015/03/02/1-5-million-at-risk-in-pa-for-crude-oil-derailment/.

Kinchy, A.J., K. Jalbert, and J. Lyons. 2014. “What Is Volunteer Water Monitoring Good for? Fracking and the Plural Logics of Participatory Science." In Fields of Knowledge: Science, Politics and Publics in the Neoliberal Age (Political Power and Social Theory, Volume 27), edited by David J Hess and Scott Frickel, 259-289. Political Power and Social Theory. Bingley, UK: Emerald Group Publishing. doi:10.1108/S0198-871920140000027017.

Kinchy, A.J., and S.L. Perry. 2012. "Can Volunteers Pick Up the Slack? Efforts to Remedy Knowledge Gaps About the Watershed Impacts of Marcellus Shale Gas Development." Duke Environmental Law \& Policy Forum 22 (2): 303-339. 
Kleinman, D.L., and S.P. Vallas. 2001. "Science, Capitalism, and the Rise of The 'knowledge Worker': The Changing Structure of Knowledge Production in the United States." Theory and Society, 451-492.

Konschnik, K., M. Holden, and A. Shasteen. 2013. “Legal Fractures in Chemical Disclosure Laws: Why the Voluntary Chemical Disclosure Registry FracFocus Fails as a Regulatory Compliance Tool." Harvard Law School: Environmental Law Program Policy Initiative. https:// blogs.harvard.edu/environmentallawprogram/files/2013/04/4-23-2013-LEGALFRACTURES.pdf.

Lave, R. 2012. "Neoliberalism and the Production of Environmental Knowledge." Environment and Society: Advances in Research 3 (1): 19-38. Accessed 3 April 2013. doi:10.3167/ares. 2012.030103.

Malloy, D. 2011. "Some Water Treatment Plants Refuse to Take Fracking Fluid." Pittsburgh PostGazette, April 13. Accessed 12 July 2017. http://www.post-gazette.com/news/nation/ 2011/04/13/Some-water-treatment-plants-refuse-to-take-fracking-fluid/stories / 201104130129.

Malone-Rubright, S. 2015. "Danger Around the Bend: The Threat of Oil Trains in Pennsylvania." FracTracker Alliance, March 2. Accessed 12 July 2017. https://www.fractracker.org/2015/03/ danger-around-bend/.

Malone-Rubright, S., and M. Kelso. 2014. “Oil Trains Passing Through Pittsburgh: A Pilot Train Count." FracTracker Alliance, December 2. Accessed 12 July 2017. http:// www.fractracker.org/2014/12/oil-trains-pittsburgh/.

Malone, S., M. Kelso, T. Auch, K. Edelstein, K. Ferrar, and K. Jalbert. 2015. “Data Inconsistencies from States with Unconventional Oil and Gas Activity." Journal of Environmental Health and Science 50 (5): 37-41. doi:10.1080/10934529.2015.992678.

Malone, S., M. Kelso, D. Michanowicz, K. Ferrar, K.N. Shields, and J. Kriesky. 2012. "FracTracker Survey and Case Studies : Application for Participatory GIS in Unconventional Natural Gas Development." Environmental Practice 14 (4): 342-351. Accessed 11 July 2017. doi:10.1017/ S1466046612000324.

Masur, D., C. Coffman, B. Lenker, M. Kelso, and S. Malone. 2015. "Danger Around the Bend: The Threat of Oil Trains in Pennsylvania," February 2. Accessed 11 January 2016. http:// www.fractracker.org/2015/03/danger-around-bend/.

Matz, J., and D. Renfrew. 2015. "Selling 'Fracking': Energy in Depth and the Marcellus Shale." Environmental Communication 9 (3): 288-306. doi:10.1080/17524032.2014.929157. 
Maule, A.L., C.M. Makey, E.B. Benson, I.J. Burrows, and M.K. Scammell. 2013. "Disclosure of Hydraulic Fracturing Fluid Chemical Additives: Analysis of Regulations." NEW SOLUTIONS: A Journal of Environmental and Occupational Health Policy 23 (1): 167-187. doi: 10.2190/NS.23.1.j.

Mazzarella, W. 2004. "Culture, Globalization, Mediation." Annual Review of Anthropology 33 (1): 345-367. doi:10.1146/ annurev.anthro.33.070203.143809.

Mazzarella, W. 2006. "Internet X-Ray: E-Governance, Transparency, and the Politics of Immediation in India." Public Culture 18 (3): 473-505. doi:10.1215/08992363-2006-016.

McCormick, S. 2009. Mobilizing Science: Movements, Participation, and the Remaking of Knowledge. Social Forces. Philadelphia: Temple University Press.

Michanowicz, D., S. Malone, M. Kelso, K. Ferrar, C. Christen, and C.D. Volz. 2012. "A Participatory Geographic Information System (PGIS) Utilizing the GeoWeb 2.0: Filling the Gaps of the Marcellus Shale Natural Gas Industry" 10 (3): 45-53.

Milan, S. 2015. "From Social Movements to Cloud Protesting: The Evolution of Collective Identity." Information, Communication \& Society 18 (8): 887-900. doi:10.1080/1369118X. 2015.1043135.

Milan, S., and L. Van Der Velden. 2016. "The Alternative Epistemologies of Data Activism." Digital Culture E Society 2 (2): 57-74.

Moore, D. 2015. “Train Derailment Could Affect 183,000 in Pittsburgh, Study Says." Pittsburge Post-Gazette, March 2. Accessed 11 January 2016. http://powersource.post-gazette.com/ powersource / policy-powersource / 2015/03/02/Groups-highlight-risk-of-crude-oil-trainderailments-in-Pittsburgh/stories/201503020128.

Murphy, M. 2004. "Uncertain Exposures and the Privilege of Imperception : Activist Scientists and Race at the US Environmental Protection Agency." Osiris 19: 266-282.

New York State Department of Environmental Conservation. 2015. "Generic Environmental Impact Statement on the Oil, Gas and Solution Mining Regulatory Program (GEIS)." Accessed 11 January 2016. http:/ / www.dec.ny.gov/ energy / 45912.html.

New York State Department of Health. 2014. New York State Department of Health Completes Review of High-Volume Hydraulic Fracturing. Albany, NY. Accessed 22 April 2015. https:// www.health.ny.gov/press/releases/2014/2014-12-17 fracking report.htm.

New York State Office of the Governor. 2014. "New York State Governor's Cabinet Meeting." December 17. Accessed 11 January 2016. https://www.youtube.com/watch? $\underline{\mathrm{v}=\mathrm{rTIn} 161 \mathrm{KyN} 4}$. 
New Yorkers Against Fracking. 2015. “Facts About Fracking: Reports." Accessed 11 January 2016. http:/ / nyagainstfracking.org/category/reports/.

Northrup, C. 2014. "The (Real) History of New York State Frack Bans." No Fracking Way: Speaking Out to Protect Our Communities and Environment. Accessed 11 January 2016. http:// www.nofrackingway.us/2014/07/05/the-real-history-of-new-york-state-bans /.

Ottinger, G. 2009. "Buckets of Resistance: Standards and the Effectiveness of Citizen Science." Science, Technology \& Human Values 35 (2): 244-270. Accessed 1 September 2011. doi: $10.1177 / 0162243909337121$.

Pennsylvania Department of Environmental Protection. 2016. Instructions for Completing an Application for a Permit to Drill or Alter an Oil or Gas Well. Accessed 11 July 2017. http:// www.elibrary.dep.state.pa.us/dsweb/Get/Document-110820/8000-PM-OOGM0001 Instructions.pdf.

Pennsylvania Office of the Governor. 2015. "Governor Wolf Releases Oil Train Safety Report," August 17. Accessed 11 January 2016. https://www.governor.pa.gov/governor-wolfreleases-oil-train-safety-report $/$.

Phillips, S. 2016. "Lack of Data on Fracking Spills Leaves Researchers in the Dark on Water Contamination." NPR StateImpact Pennsylvania, January 22. Accessed 12 July 2017. https:// stateimpact.npr.org/pennsylvania/2016/01/22/lack-of-data-on-fracking-spills-leavesresearchers-in-the-dark-on-water-contamination/.

Public Accountability Initiative. 2015. “Freedom Fracked?" Accessed 11 July 2017. http:/ / publicaccountability.org/2015/06/freedom-fracked/ - map4; http://public-accountability.org/ 2015/06/freedom-fracked/.

Rabinowitz, P.M., I.B. Slizovskiy, V. Lamers, S.J. Trufan, T.R. Holford, J.D. Dziura, P.N. Peduzzi, et al. 2015. "Proximity to Natural Gas Wells and Reported Health Status: Results of a Household Survey in Washington County, Pennsylvania." Environmental Health Perspectives 123 (1): 21-26. doi:10.1289/ehp.1307732.

Rich, A.L., and E.C. Crosby. 2013. “Analysis of Reserve Pit Sludge from Unconventional Natural Gas Hydraulic Fracturing and Drilling Operations for the Presence of Technologically Enhanced Naturally Occurring Radioactive Material (TENORM)." New Solutions : A Journal of Environmental and Occupational Health Policy: NS 23 (1): 117-135. doi:10.2190/NS.23.1.h.

Roberts, J.A., and N. Langston. 2008. "Toxic Bodies/Toxic Environments: An Interdisciplinary Forum." Environmental History 13 (October): 629-635. Accessed 7 October 2013. http:// www.nancylangston.net/uploads/3/6/3/0/3630893/robertslangston2008.pdf. 
Robinson, D., H. Yu, W.P. Zeller, and E.W. Felten. 2009. "Government Data and the Invisible Hand." Yale Journal of Law and Technology 11 (1).

Ruppert, E. 2015. "Doing the Transparent State: Open Government Data as Performance Indicators." In The World of Indicators: The Making of Governmental Knowledge Through Quantification, edited by Richard Rottenburg, Sally E Merry, Sung-Joon Park, and Johanna Mugler, 127-150. Cambridge, UK: Cambridge University Press.

Schrock, A.R. 2016. "Civic Hacking as Data Activism and Advocacy: A History from Publicity to Open Government Data." New Media \& Society 18 (4): 581-599. doi: $10.1177 / 1461444816629469$.

Simonelli, J. 2014. "Home Rule and Natural Gas Development in New York: Civil Fracking Rights." Journal of Political Ecology 21 (1): 258-278.

Soeder, B.D.J., and W.M. Kappel. 2009. "Water Resources and Natural Gas Production from the Marcellus Shale." US Department of the Interior, US Geological Survey. Accessed 11 July 2017. https://pubs.usgs.gov/fs/2009/3032/.

Starbuck, A. 2015. "Federal Railroad Administration to Issue Additional Standards to Prevent Oil Train Derailments." Center for Effective Government, October 9. Accessed 11 January 2016. http:// www.foreffectivegov.org/blog/federal-railroad-administration-issue-additionalstandards-prevent-oil-train-derailments.

Tate, C. 2015. "Railroads Use New Oil Train Rule to Fight Transparency I McClatchy DC." McClatchy Washington Bureau, June 25. Accessed 11 January 2016. http:// www.mcclatchydc.com/news/nation-world/national/economy/article25776997.html.

Transportation Safety Board of Canada. 2014. Lac-Mégantic Runaway Train and Derailment Investigation Summary. Accessed 11 January 2016. http://www.tsb.gc.ca/eng/rapportsreports/rail/2013/r13d0054/r13d0054-r-es.asp.

Troutman, M., S. Shamer, and J. Pribanic. 2017. "Hidden Data Suggests Fracking Created Widespread, Systemic Impact in Pennsylvania." Public Herald, January 23. Accessed 11 July 2017. http://publicherald.org/hidden-data-suggests-fracking-created-widespreadsystemic-impact-in-pennsylvania $/$.

United States Department of Transportation. 2011. Authorization to Share Security Information (SSI) With Complainants and Other Parties Involved in Surface Transportation (STB) Administrative Proceedings. Washington, D.C. Accessed 11 January 2016. https://www.stb.dot.gov/stb/ docs/Economic Data/SSI order and memo - STB proceedings07292011 0000.pdf. 
United States Department of Transportation. 2012. Emergence Response Guidebook. Washington, D.C. Accessed 11 January 2016. http://phmsa.dot.gov/pv obj cache/ pv_obj_id_7410989F4294AE44A2EBF6A80ADB640BCA8E4200/ filename/ERG2012.pdf.

United States Department of Transportation. 2014. Emergency Restriction/Prohibition Order. Washington, D.C. Accessed 11 January 2016. https://www.transportation.gov/briefingroom/emergency-order.

United States Energy Information Agency. 1993. Drilling Sideways -- A Review of Horizontal Well Technology and Its Domestic Application, DOE/EIA-TR-0565. Washington, D.C. Accessed 28 July 2015. http://www.eia.gov/pub/oil gas/natural gas/analysis publications/ drilling sideways well technology/pdf/tr0565.pdf.

United States Environmental Protection Agency. 2011. "Lifting of Administrative Stay for Hydrogen Sulfide." Toxic Release Inventory. Accessed 11 January 2016. http: / / www.epa.gov/ toxics-release-inventory-tri-program/lifting-administrative-stay-hydrogen-sulfide.

Urbina, I., and J.C. McGinty. 2011. “Learning Too Late of the Perils in Gas Well Leases." New York Times, December 1. Accessed 12 July 2017. http://www.nytimes.com/2011/12/02/us/ drilling-down-fighting-over-oil-and-gas-well-leases.html.

Verbeek, P.-P. 2006. "Materializing Morality: Design Ethics and Technological Mediation." doi: $10.1177 / 0162243905285847$.

Warner, B., and J. Shapiro. 2013. "Fractured, Fragmented Federalism: A Study in Fracking Regulatory Policy." Publius 43 (3): 474-496. doi:10.1093/publius/pjt014.

Wylie, S.A., and S. Dosemagen. 2011. "Public Lab Aims for Affordable Hydrogen Sulfide Gas Sensors." MediaShift, October 25. Accessed 11 July 2017. http://mediashift.org/2011/10/ public-lab-aims-for-affordable-hydrogen-sulfide-gas-sensors294/.

Wylie, S.A., K. Jalbert, S. Dosemagen, and M. Ratto. 2014. “Institutions for Civic Technoscience: How Critical Making Is Transforming Environmental Research." The Information Society 30 (2): 116-126. doi:10.1080/01972243.2014.875783.

Wynne, B. 1996. "May the Sheep Safely Graze? A Reflexive View of the Expert-Lay Knowledge Divide." In Risk, Environment and Modernity: Towards a New Ecology, edited by S. Lash, S. Bronislaw, and B. Wynne, 44-83. London, UK: Sage.

Yu, H., and D.G. Robinson. 2012. “The New Ambiguity of 'Open Government.'” 59 UCLA L Rev Disc 178 (2012): 178-208. doi:http:/ / dx.doi.org/10.2139/ssrn.2012489.

Zhang, T., D. Bain, R. Hammack, and R.D. Vidic. 2015. “Analysis of Radium-226 in High Salinity Wastewater from Unconventional Gas Extraction by Inductively Coupled Plasma-Mass 
Spectrometry." Environmental Science \& Technology 49 (5). American Chemical Society: 29692976. Accessed 11 July 2017. doi:10.1021/ es504656q. 